\title{
E-Santri Sebagai Aplikasi Pembelanjaan dan Pembayaran Mandiri oleh Santri di Pondok Pesantren Az Zubair
}

\author{
Moh Zayyadi ${ }^{1}$ dan Abd. Wahab Syahroni \\ ${ }^{1}$ Pendidikan Matematika, Universitas Madura, Jalan Raya Panglegur, Pamekasan, Indonesia, 69371 \\ ${ }^{2}$ Jurusan Informatika, Universitas Madura, Jalan Raya Panglegur, Pamekasan, Indonesia, 69371 \\ *Email Korespondensi: zayyadi@unira.ac.id
}

\begin{abstract}
Abstrak
Transaksi belanja, sanksi dan pembayaran di Pondok Pesantren Az Zubair masih menggunakan sistem transaksi manual yaitu menggunakan catatan manual dan uang tunai. Beberapa transaksi yang ada di Pondok Pesantren antara lain transaksi pembayaran kewajiban bulanan, mini market atau kantin, pembayaran jasa dan pembayaran denda atau hukuman. Transaksi yang dilakukan secara manual sangat rawan pencurian dan susah dilacak, sulit melakukan rekapitulasi serta bisa menjadi salah satu penularan kuman, bakteri atau virus yang menempel pada uang tunai. Penerapan aplikasi eSantri sebagai aplikasi pembelanjaan dan pembayaran mandiri oleh santri di Pondok Pesantren Az Zubair bertujuan memberikan informasi secara terbuka dan langsung kepada santri terkait tagihan pembayaran kewajiban santri, melatih santri agar terbiasa dengan transaksi non tunai meskipun hanya dilakukan dalam jaringan lokal pondok pesantren dengan menggunakan kartu santri yang didalamnya terdapat password dan saldo. Metode pelaksanaan yang digunakan adalah sosialisasi dan pelatihan dan metode pengembangan aplikasi menggunakan metode prototype. Setelah aplikasi selesai dibuat, tim pengabdian melakukan pelatihan kepada santri, selain itu tim pengabdian juga telah membuatkan buku panduan penggunaan aplikasi eSantri. Kegiatan pengabdian ini dilakukan mulai april hingga agustus 2020. Berdasarkan hasil survey kepada 80 responden menggunakan skala likert terhadap implementasi aplikasi eSantri di pondok pesantren menyatakan sangat setuju dengan kegiatan pengabdian ini dengan nilai persentasi kepuasan sebesar $81,75 \%$.
\end{abstract}

Kata kunci: eSantri; aplikasi pembayaran; pembelanjaan; pondok pesantren.

\begin{abstract}
Shopping, sanctions and payment transactions at the Az Zubair Islamic Boarding School still use the manual transaction system, using manual notes and cash. Some of the transactions in Islamic boarding schools include monthly payment transactions, mini markets or canteen, payment for services and payment of fines or penalties. Transactions that are carried out manually are very prone to theft and difficult to trace, difficult to recapitulate and can be one of the transmissions of germs, bacteria or viruses that stick to cash. The application of the eSantri as an independent spending and payment application by students at the Az Zubair Islamic Boarding School aims to provide information openly and directly to students regarding the payment of students obligations, train students to be familiar with non-cash transactions even though it is only done in the local boarding school network using a card students in which there is a password and balance. The implementation method used is socialization and training. The application development method uses the prototype method. After the application is made, the team conducts training for students, besides that the team has also made a manual book for using the eSantri application. This activity was carried out from April to August 2020. Based on the results of a survey of 80 responden using a Likert scale on the implementation ot the eSantri application in Islamic boarding schools, they strongly agreed with this activity with a satisfaction percentage value of $81.75 \%$.
\end{abstract}

Keywords: eSantri; payment application; spending; islamic boarding schools

Format Sitasi: Zayyadi, M., Syahroni, A.W. (2020). E-Santri Sebagai Aplikasi Pembelanjaan dan Pembayaran Mandiri oleh Santri di Pondok Pesantren Az Zubair. Jurnal Solma, 09(2), 300-307. Doi: http://dx.doi.org/10.22236/solma.v9i2.5427 Diterima: 21 Agustus 2020 | Revisi: 05 September 2020 | Dipublikasikan: 30 Oktober 2020. 
(C) 2020 Oleh authors. Lisensi Jurnal Solma, LPPM-Uhamka, Jakarta. Artikel ini bersifat open access yang didistribusikan di bawah syarat dan ketentuan Creative Commons Attribution (CC BY) license. (http://creativecommons.org/licenses/by/4.0/).

\section{PENDAHULUAN}

Pondok Pesantren adalah tempat pendidikan yang mengharuskan siswanya (santri) tinggal bersama dan belajar dibawah bimbingan kiai dan ustad selama kurun waktu tertentu (Budiyanto \& Machali, 2014). Pondok Pesantren merupakan replika kehidupan masyarakat karena didalamnya terjadi banyak pengalaman kehidupan yang dirasakan oleh santri (Syahroni \& Ubaidi, 2018a). Mulai dari belanja, makan, belajar, hukuman serta melakukan kewajiban pembayaran. Terdapat beberapa kegiatan pembayaran yang dilakukan di pondok pesantren antara lain pembayaran kewajiban bulanan kepada pondok pesantren, pembayaran belanja (minimarket dan kantin), pembayaran jasa di pondok pesantren serta pembayaran denda atau hukuman.

Pondok Pesantren Az Zubair merupakan pondok pesantren yang beralamat di Dusun Sumber Anyar, Desa Larangan Tokol, Kecamatan Tlanakan, Kabupaten Pamekasan, Madura. Sistem pembelanjaan dan pembayaran di Pondok Pesantren Az Zubair masih menggunakan sistem transaksi manual yaitu catatan manual dan uang tunai. Bank Indonesia pernah mencanangkan program Gerakan Nasional Non Tunai (GNNT) pada tahun 2014. Pencanangan ini telah mendapatkan persetujuan dari Kementrian Koordinator Bidang Perekonomian, Kementrian Keuangan, Pemerintah Daerah serta Asosiasi Pemerintah Provinsi seluruh Indonesia sebagai komitmen untuk mendukung kegiatan ini (GNNT, 2019). GNNT ini dimaksudkan untuk meningkatkan kesadaran masyarakat, pelaku bisnis dan juga lembaga-lembaga pemerintah untuk menggunakan sarana pembayaran non tunai dalam melakukan transaksi keuangan, yang tentunya mudah, aman dan efisien, sehingga berangsur-angsur terbentuk suatu komunitas atau masyarakat yang lebih menggunakan instrumen non tunai (Less Cash Society/LCS) khususnya dalam melakukan transaksi atas kegiatan ekonominya (Hastuti \& Suhadak, 2019).

Sebagai bentuk komitmen atas perluasan penggunaan instrument non tunai dan menjadikan GNNT sebagai kegiatan untuk mendorong meningkatkan pemahaman masyarakat akan penggunaan transaksi non tunai maka implementasi GNNT ini dalam kehidupan Pondok Pesantren perlu untuk dilakukan.

Sistem informasi merupakan suatu sistem yang menyediakan informasi untuk manajemen dalam mengambil keputusan serta menjalankan operasional instansi atau lembaga, di mana sistem tersebut merupakan kombinasi dari orang-orang, teknologi informasi dan prosedur-prosedur yang tergorganisasi (Raymond, 2013). Penggunaan aplikasi atau sistem informasi saat ini telah menjadi kebutuhan primer bagi semua orang utamanya bagi para pekerja atau pelajar karena akan mempermudah seluruh pekerjaan dan mempersingkat waktu (Fajriah, Kobajashi, Mustafa, \& Arami, 2020).

\section{MASALAH}

Sebelum pembuatan aplikasi eSantri ini, tim pengabdian pernah melakukan pengabdian pada pondok pesantren Az Zubair dengan membuatkan 4 aplikasi yang mendukung GNNT ini antara lain (1) aplikasi e-bank merupakan aplikasi utama untuk 
memasukkan data santri, cetak kartu santri, penambahan saldo kartu santri, rekap transaksi dari semua aplikasi dan pembuatan akun aplikasi yang lain, (2) e-mart merupakan aplikasi minimarket atau kantin, (3) e-payment merupakan aplikasi pembayaran kewajiban dan denda santri dan (4) t-cash merupakan aplikasi pembayaran jasa. Semua aplikasi tersebut menggunakan kartu santri yang didalamnya terdapat saldo dan password. Namun setiap transaksi pada aplikasi tersebut masih melibatkan admin masing masing aplikasi.

Dalam pengabdian ini, tim pengabdian melakukan terobosan baru dengan membuatkan aplikasi eSantri agar transaksi pembelanjaan dan pembayaran kewajiban serta denda atau hukuman dapat dilakukan sendiri oleh santri (mandiri) melalui aplikasi. Santri tidak lagi membutuhkan uang tunai melainkan menggunakan uang digital atau virtual. Penggunaan uang digital atau virtual lebih memudahkan dalam melakukan transaksi (Falani \& Hidayatullah, 2018; Pilone \& Pitman, 2005). Kegiatan transaksi pembelian barang dengan menggunakan aplikasi juga tidak perlu menggunakan uang kembalian (Santosa, 2010).

Adapun fitur yang ada pada aplikasi eSantri ini antara lain (1) login menggunakan username dan password kartu santri, (2) pembayaran kewajiban pondok seperti syahriyah atau tagihan bulanan, (3) pembayaran insidental seperti mengikuti les atau kegiatan tertentu, (4) transfer uang antar santri, (5) terima uang transfer antar santri, (6) pengajuan tarik tunai kepada pihak e-bank, (7) tabungan, (8) pembayaran denda berupa uang, (9) informasi denda berupa hukuman, dan (10) transaksi pembelian pada kantin.

\section{METODE PELAKSANAAN}

Metode yang digunakan adalah metode prototype untuk pengembangan aplikasi dan metode pelatihan untuk penggunaan aplikasi. Adapun langkah langkah dari metode prototype antara lain analisa kebutuhan, menterjemahkan data yang telah dianalisis ke dalam bentuk yang mudah di mengerti oleh pihak pondok pesantren (mitra), evaluasi terhadap aplikasi yang sudah jadi dan bila terdapat kekurangan pada aplikasi bisa ditambahkan hingga semua kebutuhan mitra terpenuhi, dan yang terakhir produk rekayasa atau aplikasi yang sudah siap digunakan (Syahroni \& Ubaidi, 2018b). Setelah aplikasi siap digunakan, tim pengabdian melakukan instalasi aplikasi dan jaringan agar aplikasi dapat terhubung dengan server.

Setelah aplikasi siap digunakan, tim pengabdian memberikan pelatihan dan demo aplikasi kepada beberapa pengurus dan santri terkait cara penggunaan aplikasi eSantri. Selain itu, tim pengabdian juga membuatkan buku panduan penggunaan aplikasi eSantri sebagai bentuk teori agar pengurus dan santri dapat belajar sendiri tanpa panduan tim pengabdian pada masa yang akan datang. Hal ini sesuai dengan melalui pembuatan buku bantuan (modul) dapat membantu pengurus dan santri dalam mengoperasikan aplikasi dikarenakan dalam kegiatan pengabdian tidak hanya melulu praktek saja tetapi juga ada teori disampaikan (Subaidi, Zayyadi, Hasanah, \& Halim, 2019; Zayyadi, Lanya, \& Irawati, 2019; Zayyadi, Supardi, \& Misriyana, 2017).

\section{HASIL DAN PEMBAHASAN}

Kegiatan pengabdian kepada masyarakat ini dilakukan oleh tim pengabdi utama yang berjumlah 2 orang, dibantu oleh 2 mahasiswa, dan 1 sekretaris pengabdian. Kegiatan ini 
melibatkan pengurus pondok pesantren dan santri di pondok pesantren Az Zubair terdiri dari 3 tahapan yakni 1) tahapan pembuatan aplikasi, 2) tahapan pelatihan dan 3) survey kepuasan.

1) Tahapan pembuatan aplikasi

Tahap pertama ini berupa analisa kebutuhan sistem yang akan dibuat kepada pengurus dan santri, kemudian tim menterjemahkan data yang telah dianalisis ke dalam bentuk yang mudah di mengerti oleh pihak pondok pesantren kedalam bentuk aplikasi awal, setting jaringan komputer, kemudian pengurus melakukan evaluasi terhadap aplikasi yang sudah jadi dan bila terdapat kekurangan pada aplikasi bisa ditambahkan hingga semua kebutuhan terpenuhi dan aplikasi siap digunakan.

Berikut tampilan desain jaringan komputer yang dipasang pada pengabdian ini:

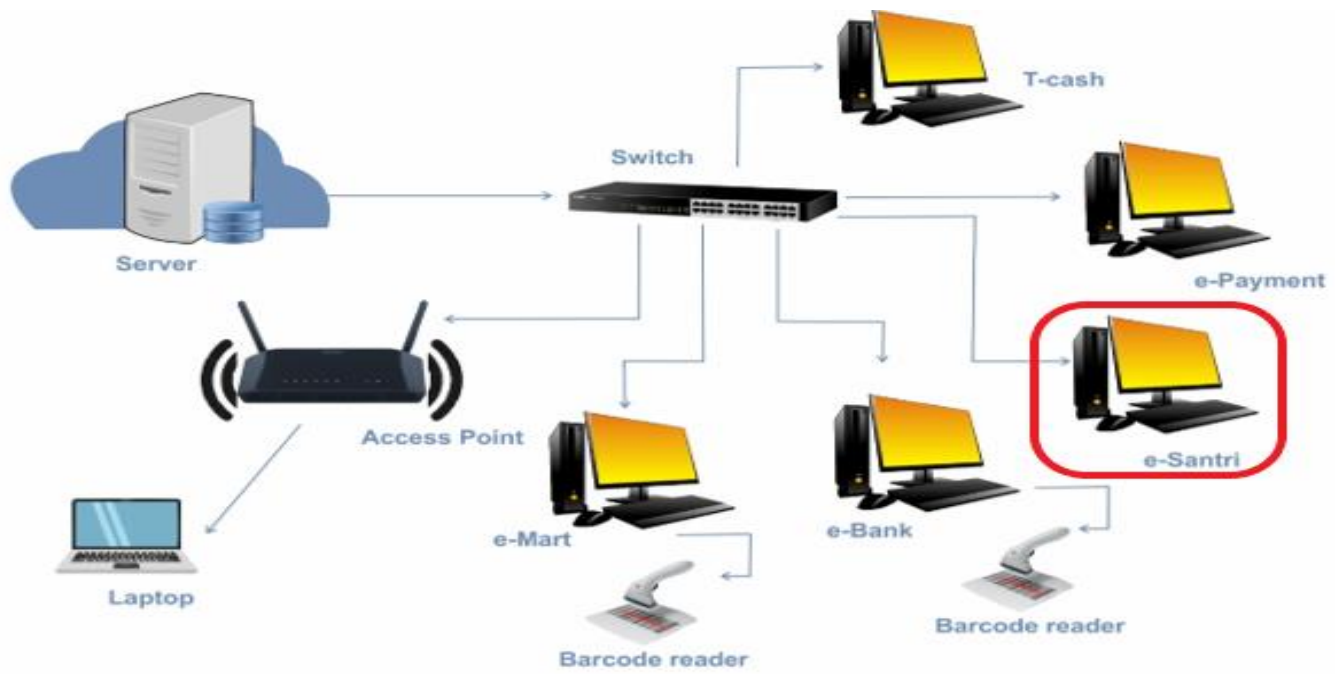

Gambar 1. Skema Setting Jaringan eSantri

Kendala yang dihadapi pada setting jaringan komputer ini adalah koneksi ke server melalui laptop menggunakan access point karena tidak bisa dibuatkan IP Address secara dinamis (IP Statis). IP Address Laptop harus di setting secara manual agar dapat terhubung ke server. Ini menjadi kendala, karena laptop yang digunakan untuk mengakses aplikasi eSantri terkadang digunakan untuk kegiatan lain oleh pengurus yang mengharuskan terhubung ke internet dan membutuhkan perubahan IP Address. Sehingga pengurus mengalami kesulitan saat ingin koneksi ke server aplikasi eSantri kembali. 


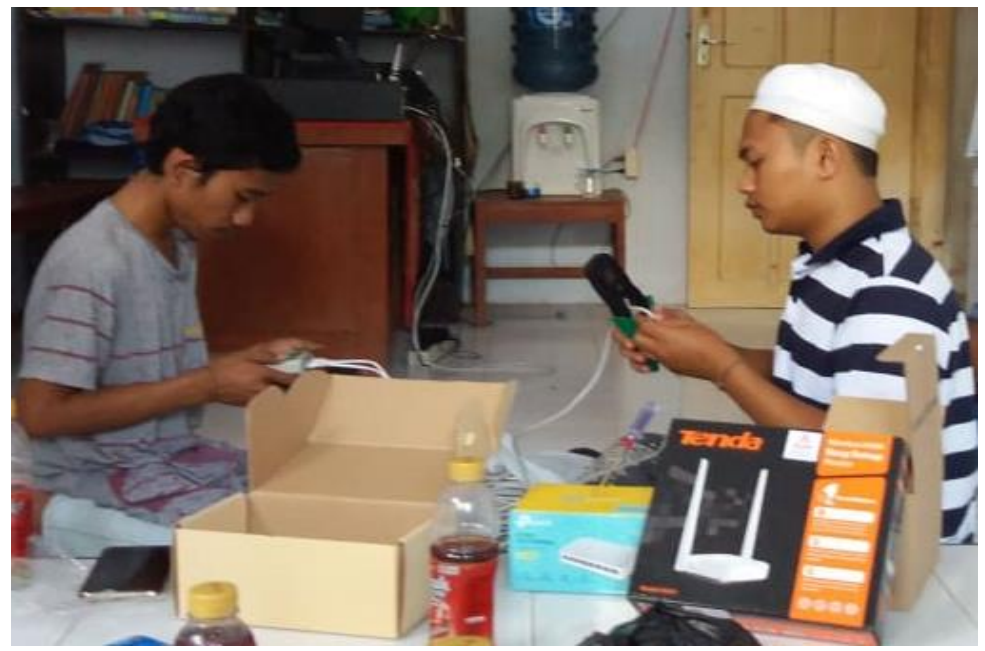

Gambar 2: Setting Jaringan eSantri di Pondok Pesantren

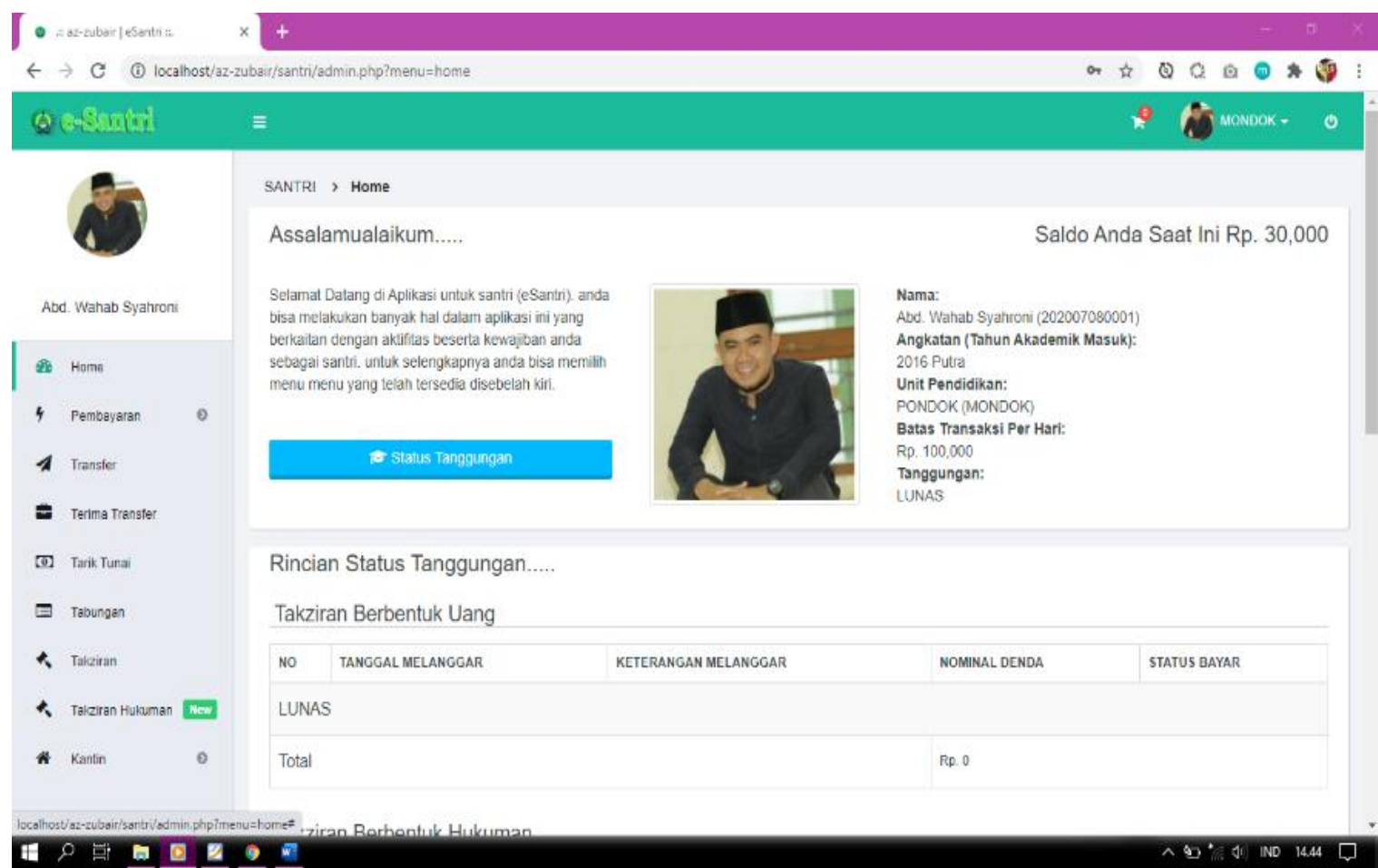

Gambar 3: Tampilan Aplikasi e-santri

\section{2) Tahapan pelatihan}

Setelah aplikasi selesai dibuat dan di evaluasi, tim pengabdian melakukan pelatihan kepada pengurus dan santri terkait penggunaan aplikasi. Setelah aplikasi digunakan, tim pengabdian melakukan evaluasi kepuasan penggunaan aplikasi kepada pengurus dan santri. 


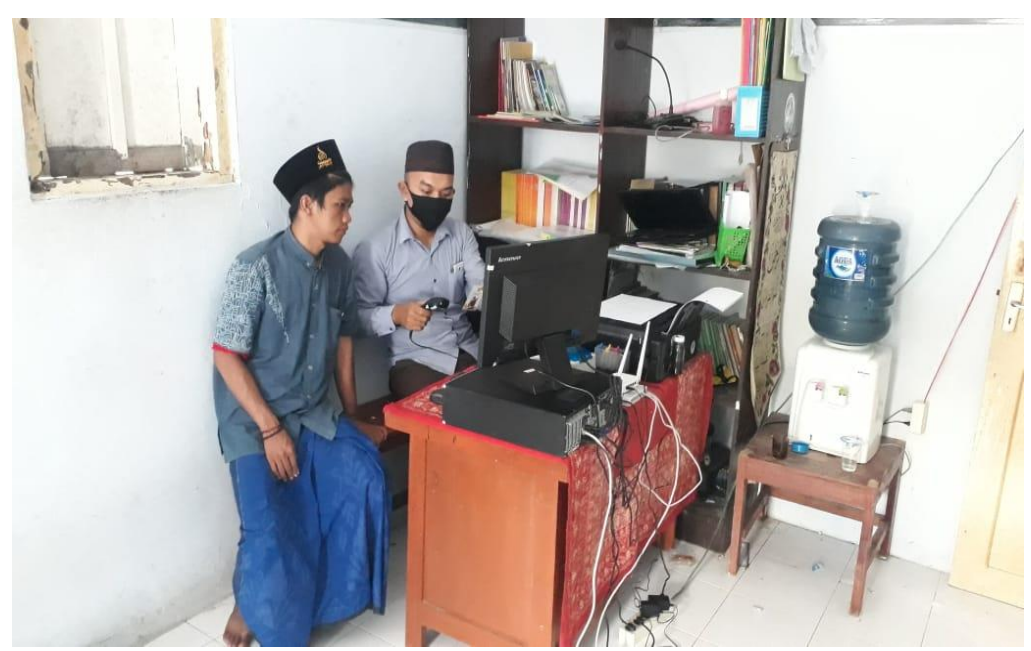

Gambar 4: Pelatihan Penggunaan Aplikasi e-santri

Kendala yang dihadapi pada kegiatan pelatihan ini adalah tidak dapat dilakukan pelatihan secara bersama sama dengan semua pengurus sekaligus dikarenakan masih masa pandemi COVID19. Sehingga tim pengabdian melakukan pelatihan penggunaan aplikasi secara satu persatu kepada pengurus. Ini memakan waktu yang lama karena mengulang ulang kegiatan yang sama kepada orang yang berbeda beda. Oleh sebab itu, tim pengabdian juga telah membuatkan buku petunjuk penggunaan aplikasi.

\section{3) Survey kepuasan}

Setelah aplikasi selesai dibuat, pelatihan telah dilakukan dan aplikasi telah digunakan, langkah selanjutnya yang dilakukan oleh tim pengabdian adalah melakukan survey kepada pengurus dan santri untuk mengukur kepuasan terhadap aplikasi eSantri. Melalui pemberian survey kepuasan pada para peserta untuk dapat mengetahui perubahan pengetahuan selama proses pelaksanaan pengabdian yang dilakukan (Subaidi \& Zayyadi, 2018). Survey dilakukan kepada 80 responden yang terdiri dari 5 pengurus dan 75 santri. Dengan pertanyaan "Bagaimana pendapat anda terhadap aplikasi eSantri yang telah di implementasikan di Pondok Pesantren Az Zubair?”. Survey ini menggunakan skala likert (SL) dengan skala penilaian 5 hingga 1. Sangat setuju diberi nilai 5, setuju diberi nilai 4, cukup setuju diberi nilai 3, tidak setuju diberi nilai 2, Sangat tidak setuju diberi nilai 1. Adapun rentang nilai kepuasan yang digunakan antara lain $80 \%-100 \%=$ Sangat setuju, $60 \%-79 \%=$ Setuju, $40 \%-59 \%=$ Cukup setuju, $20 \%$ $-39 \%=$ Tidak setuju, $0 \%-19 \%=$ Sangat tidak setuju. Total skor nilai tertinggi (X) dari survey ini adalah 400. Survey ini mendapatkan tanggapan sebagai berikut 0 responden menjawab tidak setuju, 0 responden menjawab cukup setuju, 73 responden menjawab setuju dan 7 responden menjawab sangat setuju. Dari tanggapan tersebut maka didapat total nilai skor responden (Y) sebesar 327. Maka dengan menggunakan rumus $\mathrm{SL}=(\mathrm{Y} / \mathrm{X}) * 100 \%$ (Suzuki, Timor, \& Syamsiah, 2015; Syahroni, 2019). maka diperoleh nilai SL $=(327 / 400) * 100 \%$ adalah $81,75 \%$, nilai ini berada pada rentang nilai kepuasan Sangat setuju. Kegiatan tingkat kepuasan penggunaan aplikasi E-Santri terlihat pada Gambar 5. 


\section{Tingkat Kepuasan Penggunaan Aplikasi eSantri}

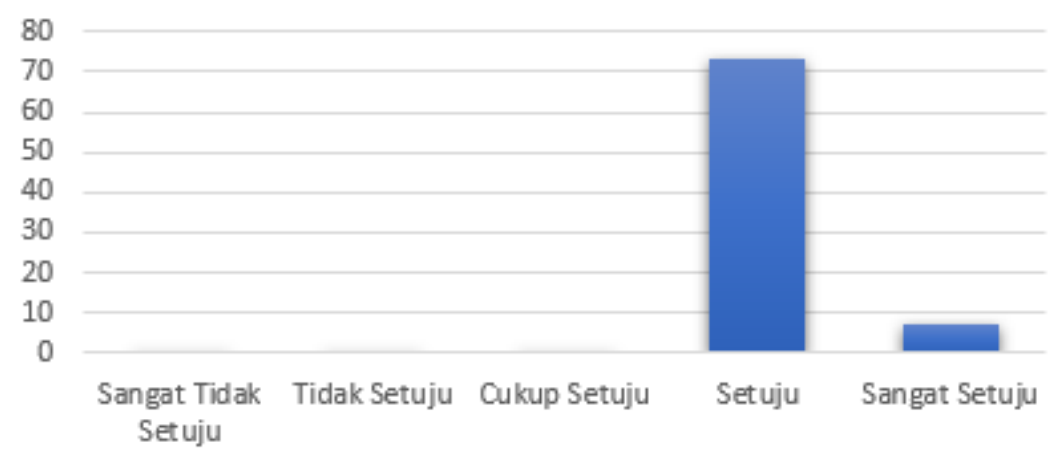

Gambar 5. Tingkat Kepuasan Penggunaan Aplikasi eSantri

Kegiatan pengabdian kepada masyarakat ini merupakan salah satu bukti implementasi bidang ilmu, sumber daya dan pengalokasian dana yang digunakan untuk kepentingan peningkatan pelayanan yang ada di pondok pesantren. Keberadaan aplikasi output dari kegiatan pengabdian ini diharapkan dapat meningkatkan pelayanan transaksi pembelanjaan dan pembayaran di pondok pesantren juga sebagai sarana implementasi GNNT ini dalam kehidupan Pondok Pesantren sehingga berangsur-angsur terbentuk suatu komunitas atau masyarakat yang lebih menggunakan instrumen non tunai (Less Cash Society/LCS) khususnya dalam melakukan transaksi atas kegiatan ekonominya. Sehingga dalam pengabdian ini dapat memberikan manfaat bagi pondok pesantren.

\section{KESIMPULAN}

Kegiatan pengabdian ini telah memberikan pengalaman yang sangat berharga kepada santri karena dapat belajar sekaligus implementasi transaksi non tunai dalam lingkungan pondok pesantren. Selain itu, kegiatan pengabdian ini dapat diterima dengan baik oleh pondok pesantren terbukti dengan tingkat kepuasan terhadap penggunaan aplikasi sebesar $81,75 \%$ yang artinya pengurus dan santri sangat setuju dengan penggunaan aplikasi eSantri ini di lingkungan pondok pesantren.

Adapun saran dari hasil kegiatan ini antara lain (1) dibutuhkan sumber daya manusia yang mengerti akan teknologi komputer dan jaringan, sehingga pondok pesantren tidak terlalu bergantung kepada tim pengabdian. (2) Program ini diharapkan terus berlanjut melalui dukungan pemerintah kabupaten pamekasan hingga terlihat hasil nyata bagi pondok pesantren. (3) aplikasi dapat terus dikembangkan dengan teknologi mutakhir sehingga kedepan semua pondok pesantren dapat menggunakan transaksi non tunai dalam kegiatan transaksi pembelanjaan dan pembayaran kewajiban santri.

\section{UCAPAN TERIMA KASIH}

Direktorat Riset dan Pengabdian Masyarakat, Direktorat Jenderal Penguatan Riset dan Pengembangan Kementerian Riset, Teknologi, dan Pendidikan Tinggi Republik Indonesia. Prodi Informatika, Fakultas Teknik, Universitas Madura. LPPM Universitas Madura dan Pondok Pesantren Az Zubair Pamekasan. 


\section{DAFTAR PUSTAKA}

Budiyanto, M., \& Machali, I. (2014). Pembentukan Karakter Mandiri Melalui Pendidikan Agriculture Di Pondok Pesantren Islamic Studies Center Aswaja Lintang Songo Piyungan Bantul Yogyakarta. Jurnal Pendidikan Karakter, 4(2).

Fajriah, Kobajashi, T. ., Mustafa, A., \& Arami, H. (2020). Penerapan Teknologi Aplikasi SIPTA Guna Mendukung PKW Minapolitan Swasembada Pangan Ikan di Kabupaten Konawe Utara. Celebes Abdimas: Jurnal Pengabdian Kepada Masyarakat, 2(1).

Falani, A. Z., \& Hidayatullah, M. (2018). Implementasi Library Active Merchant Sebagai Virtual Bank Dalam Aplikasi E-Commerce". Jurnal WAHANA, Universitas PGRI Adi Buana Surabaya.

GNNT. (2019). Siaran Pers. Available at: https://www.bi.go.id/id/ruang-media/siaranpers/pages/sp_165814.aspx [Diakses 1 Agustus 2019].

Hastuti, M., \& Suhadak. (2019). Analisis Pengaruh Gnnt (Gerakan Nasional Non Tunai) Terhadap Nilai Transaksi Nasabah Dan Dampaknya Terhadap Makroekonomi Indonesia. Jurnal Administrasi Bisnis, 70(1).

Pilone, D., \& Pitman, N. (2005). UML. 2.0 in Nutshell. California: O’Reilly Media.

Raymond, M. (2013). Pengertian dan Fungsi Sistem Informasi. Jakarta: PT. Prenhallindo.

Santosa, P. I. (2010). Prototipe Kantin Tanpa Uang Berbasis Kartu Pintar. Juti, 8(1), 27-32.

Subaidi, A., \& Zayyadi, M. (2018). Pelatihan Strategi Pengembangan Perpustakaan Sekolah Tingkatan Menengah Se-Kecamatan Tlanakan. JPM (Jurnal Pemberdayaan Masyarakat), 3(1), 252-258.

Subaidi, A., Zayyadi, M., Hasanah, S. I., \& Halim, D. (2019). Pelatihan Blended Learning bagi Guru Di Lingkungan Madrasah Tsanawiyah Negeri Sumber Bungur. JPM (Jurnal Pemberdayaan Masyarakat), 4(2), 388-394.

Suzuki, S., Timor, S., \& Syamsiah, N. (2015). Otomatisasi Metode Penelitian Skala Likert Berbasis Web. Seminar Nasional Sains Dan Teknologi.

Syahroni, A. W. (2019). Membangun aplikasi jam digital masjid dengan PHP dan MySQLi. Cirebon: CV Asfa Solution.

Syahroni, A. W., \& Ubaidi. (2018a). Perancangan Aplikasi E-Money dan SMS Gateway untuk Pondok Pesantren di Daerah Madura. Jurnal LINK, 27(1).

Syahroni, A. W., \& Ubaidi. (2018b). Rancang Bangun Aplikasi Jam Digital Masjid Berbasis Web. Jurnal Teknologi Informasi, 8(3).

Zayyadi, M., Lanya, H., \& Irawati, S. (2019). Geogebra dan maple sebagai media pembelajaran matematika untuk meningkatkan kualitas guru matematika. Abdimas Dewantara, 2(1), 53-61.

Zayyadi, M., Supardi, L., \& Misriyana, S. (2017). Pemanfaatan Teknologi Komputer Sebagai Media Pembelajaran Pada Guru Matematika. Jurnal Pengabdian Masyarakat Borneo, 1(2), 25-30. 